\title{
DEVELOPING MATH MODULE OF LINE MATERIAL AND CORNER IN SETTING COOPERATIVE LEARNING TYPE THINK PAIR SHARE (TPS) FOR CLASS VII SMP
}

\author{
Abdul Majid ${ }^{1)}$ \\ ${ }^{1}$ SMP Negeri 1 Patalassang, Kabupaten Gowa, Indonesia
}

\begin{abstract}
The study aims at producing package of learning module of cooperative learnig setting of think pair share type which fulfills the criteria of valid, practical, and effective. The study is research and development. The package of product to be produced consists of three components, namely lesson plan (RPP), Mathematics module learning (MPM), and test of learning result (THB). The development of the package employs 4-D Thiagarajan which conducted in four steps, namely defining phase, design phase, development phase, and dissemination phase. The result of study reveal that the package of the module is valid, practical, and effective based on the evaluation of the experts and the result of limited tryout. The validity of package of Matematics module based o the validation of experts has met valid criteria that (1) the co-efficient validity of RPP is $100 \%$, (2) the co-efficient validity of Mathematics module is $85 \%$, and (3) the co-efficient validity of THB is $83,3 \%$. These indicate that the package of Mathematics module is in valid category. The practicality of the package based on the observation of the implementation of the package has met the category of completely implemented. The effectiveness of the package has met four indicators of effectiveness which shown on (1) the percentage of classical graduates of learning result by $90,1 \%$, (2) the fulfillment of 8 categories of students' activity, (3) positive response by $80 \%$ students on learning process and Mathematics module, (4) teacher' ability in managing the learning which in good category.

Keywords: cooperative learning type think pair share (tps); Mathematics Module Learning
\end{abstract}

\section{PENDAHULUAN}

Pendidikan adalah usaha sadar dan terencana untuk mewujudkan suasana belajar dan proses pembelajaran agar peserta didik secara aktif mengembangkan potensi dirinya untuk memiliki kekuatan spiritual, keagamaan, pengendalian diri, kepribadian, kecerdasan, akhlak mulia, serta keterampilan yang diperlukan dirinya, masyarakat, bangsa dan negara UU No. 20 Tahun 2003 (Depdiknas, 2007:15).

Salah satu upaya yang disiapkan oleh Direktorat PLP adalah modul. Akan tetapi, secara umum ketersediaan modul tersebut masih terbatas yaitu masih hanya sebatas memperkenalkan pengertian materi yang diajarkan tidak memberikan secara terperinci untuk memahami materi tersebut secara mendalam atau modul yang digunakan belum mampu memberikan pemahaman penuh kepada siswa karena masih terlalu sulit untuk dipahami sendiri oleh siswa dan belum banyak modul yang mampu mengkolaborasikannya dengan model pembelajaran sehingga modul belum terlalu efektif dalam pembelajaran. Padahal pembelajaran modul ini 
mempermudah siswa untuk dapat mencapai dan menyelesaikan bahan belajarnya dengan belajar secara individual sehingga proses belajar tidak berfokus lagi pada guru melainkan siswa lagi yang aktif.

Model pembelajaran kooperatif tipe think pair share (TPS) adalah salah satu tipe dari model kooperatif yang memberi siswa waktu untuk berfikir dan merespon serta saling membantu satu sama lain. Model ini memperkenalkan ide "waktu berfikir atau waktu tunggu" yang menjadi faktor kuat dalam melakukan proses belajar mengajar, guru tidak lagi mendominasi seperti lazimnya pada saat ini, sehingga siswa dituntut untuk berbagi informasi dengan siswa yang lainnya dan saling belajar mengajar sesama siswa.dalam meningkatkan kemampuan siswa dalam merespon pertanyaan. Pembelajaran kooperatif model think pair share (TPS) ini relatif lebih sederhana karena tidak menyita waktu yang lama untuk mangatur tempat duduk ataupun mengelompokkan siswa. Pembelajaran ini melatih siswa untuk berani berpendapat dan menghargai pendapat teman (Cholis, 2006: 12).

Pernyataan masalah

Adapun pernyataan masalah dalam penelitian ini adalah dengan adanya pergeseran paradigma pembelajaran dari paradigma behavioristik ke paradigma konstruktivistik, maka guru sudah harus menerapkan Model-model pembelajaran yang berpusat pada siswa seperti model pembelajaran kooperatif tipe think pair share (TPS). Namun perangkat model pembelajaran matematika, khususnya yang berbentuk modul pembelajaran yang setting pembelajaran koopratif tipe TPS belum pernah ada.

Pertanyaan penelitian

Berdasarkan latar belakang masalah dan pernyataan masalah yang telah diuraikan, maka masalah yang dirumuskan dalam penelitian ini adalah: "Bagaimana proses dan hasil pengembangan modul matematika pada materi garis dan sudut setting pembelajaran kooperatif tipe think pair share (TPS) yang valid, praktis dan efektif untuk siswa kelas VII SMP?"

Tujuan penelitian

Sesuai dengan pertanyaan penelitian yang telah disebutkan di atas, maka tujuan pembelajarannya adalah :'Untuk menghasilkan modul matematika pada materi garis dan sudut setting pembelajaran kooperatif tipe think pair share (TPS) yang valid, praktis dan efektif untuk siswa kelas VII SMP“"

Model Pembelajaran Kooperatif

Pembelajaran kooperatif merupakan aktivitas pembelajaran kelompok yang direncanakan oleh satu prinsip bahwa pembelajaran harus didasarkan pada perubahan informasi secara sosial di antara kelompok-kelompok siswa, yang di dalamnya ada unsur tanggung jawab antar anggota kelompok terhadap tugas masing-masing dan setiap anggota didorong untuk meningkatkan kualitas 
pembelajaran secara simultan. Parker (dalam Huda, 2012:29) mendefinisikan bahwa kelompok kooperatif dipandang sebagai suasana pembelajaran dimana para siswa saling berinteraksi dalam kelompok-kelompok untuk mengerjakan tugas akademik demi mencapai tujuan bersama.

Johnson dan Johnson (dalam Huda, 2012:31) menyajikan definisi ringkas tentang kooperasi dan pembelajaran kooperatif serta membedakannya dengan pembelajaran kompetitif dan individual. Menurut Johnson dan Johnson, pembelajaran kooperatif berarti bekerja bersama-sama untuk mencapai tujuan bersama. Dalam suasana kooperatif, setiap anggota sama-sama berusaha mencapai hasil yang nantinya bisa dirasakan oleh semua anggota kelompok.

Model Pembelajaran Kooperatif tipe Think Pair Share (TPS)

Menurut (Lie, 2004:56) Model pembelajaran TPS dikembangkan oleh Frank Lyman dkk dari Universitas Maryland pada tahun 1985. Model pembelajaran TPS merupakan salah satu model pembelajaran kooperatif sederhana. Teknik ini memberi kesempatan pada siswa untuk bekerja sendiri serta bekerja sama dengan orang lain. Keunggulan teknik ini adalah optimalisasi partisipasi siswa.

Arends (dalam Komalasari, 2011: 84) mengemukakan bahwa:

"Model pembelajaran TPS merupakan suatu cara yang efektif untuk membuat variasi suasana pola diskusi kelas. Dengan asumsi bahwa semua resitasi atau diskusi membutuhkan pengaturan untuk mengendalikan kelas secara keseluruhan, dan prosedur yang digunakan dalam TPS dapat memberi murid lebih banyak waktu berfikir, untuk merespon dan saling membantu."

Modul

Pengertian modul menurut (Depdiknas, 2008: 31) adalah salah satu bentuk bahan ajar yang dikemas secara utuh dan sistematis sehingga penggunanya dapat belajar dengan atau tanpa bimbingan fasilitator/guru. Didalam modul memuat seperangkat pengalaman belajar yang terencana dan didesain untuk membantu peserta didik menguasai tujuan belajar yang spesifik.

Menurut Huoston \& Howson (dalam Riadi, 2013:35) modul pembelajaran meliputi seperangkat aktivitas yang bertujuan mempermudah siswa untuk mencapai seperangkat tujuan pembelajaran. Sedangkan menurut (Vembriarto, 1975: 19) modul dirumuskan sebagai bahan ajar yang memuat suatu konsep materi ajar.

Menurut Winkel (dalam Nurdin, 2005:34) menjelaskan bahwa modul adalah merupakan suatu program belajar mengajar terkecil yang dipelajari oleh siswa sendiri kepada dirinya sendiri (self instruksional) setelah siswa menyelesaikan yang satu dan melangkah maju dan mempelajari satuan berikutnya. Modul sebagaimana pengertian diatas merupakan salah satu media 
cetak lainnya perbedaannya dapat dilihat dari ciri-ciri yang dimiliki oleh modul itu sendiri.

Untuk menghasilkan modul yang mampu meningkatkan motivasi penggunanya, maka modul harus mencakup beberapa karakteristik tertentu. Karakteristik untuk pengembangan modul (Vembriarto, 1975: 27-29) antara lain:

(1) Self instructional

Pembelajaran dengan modul hanya memuat satu konsep atau unit bahan pelajaran.

(2) Pengakuan atas perbedaan-perbedaan individual

Dalam pembelajaran dengan modul, siswa diberi kesempatan belajar sesuai dengan kecepatan masing-masing. Sebagian modul disusun untuk diselesaikan oleh siswa secara perorangan dan sebagian modul disusun untuk diselesaikan oleh siswa dalam bentuk kelompok kecil.

(3) Memuat rumusan tujuan pengajaran secara eksplisit

Dalam modul memuat rumusan tujuan pembelajaran secara jelas dan terperinci. Rumusan tujuan yang demikian sangat berguna bagi penyusun modul, guru, dan para siswa untuk mengarahkan mereka dalam hal proses mengajar dan belajar.

(4) Adanya asosiasi, struktur, dan urutan pengetahuan

Proses asosiasi terjadi karena dengan modul siswa dapat mendengar suara guru, membaca teks, dan melihat diagram-diagram dari modulnya. Materi dalam modul dapat disusun mengikuti struktur pengetahuan secara hirarkis. Dengan demikian siswa dapat mengikuti urutan kegiatan belajar secara teratur.

(5) Penggunaan berbagai macam media (multimedia)

Karakteristik siswa terhadap kepekaan menggunakan modul dapat berbedabeda.

(6) Partisipasi aktif dari siswa

Modul disusun sedemikian rupa agar pengalaman belajar yang didapatkan siswa bermacam-macam, sehingga akan terjadi keaktifan belajar yang tinggi pada siswa.

(7) Adanya reinforcement langsung terhadap respon siswa

pembelajaran dengan modul siswa secara langsung dapat mendapatkan konfirmasi atas jawaban-jawaban yang benar melalui kunci jawaban yang tersedia pada modul.

(8) Adanya evaluasi terhadap penguasaan siswa atas hasil belajarnya.

Dalam modul terdapat kegiatan evaluasi sehingga dari hasil evaluasi ini dapat diketahui tingkat penguasaan siswa terhadap materi yang telah dipelajari 


\section{METODE PENELITIAN}

Penelitian ini adalah penelitian pengembangan (Research and Development) yakni pengembangan modul pembelajaran yang terdiri atas: tinjauan mata pelajaran, pendahuluan, kegiatan belajar, latihan, rambu-rambu jawaban latihan, rangkuman, tes formatif, dan kunci jawaban tes formatif.

Penelitian ini dilaksanakan di SMP Negeri 1 Pattallassang Kab. Gowa dan subjek penelitiannya adalah siswa kelas VII dengan jumlah 22 orang terdiri dari perempuan 10 orang dan laki-laki 12 orang.

Instrumen pengumpulan data yang digunakan dalam penelitian ini adalah lembar validasi ahli, lembar observasi, angket respons siswa, dan tes hasil belajar (THB). Tes digunakan untuk mengukur prestasi belajar siswa setelah diberikan perlakuan. Angket ditujukkan kepada siswa, untuk mengetahui pendapatnya terhadap materi pelajaran, modul pembelajaran yang digunakan serta untuk mengetahui minat siswa dalam mengikuti pembelajaran dengan model pembelajaran TPS. Untuk mengetahui kemampuan guru dalam mengelola kelas, dan aktivitas guru serta aktivitas siswa selama pembelajaran dengan modul setting pembelajaran kooperatif tipe TPS digunakan lembar obsevasi.

Prosedur pengembangan perangkat pembelajaran matematika yang digunakan mengacu pada model 4-D atau model Thiagarajan, Semme, dan Semmel (1974). Model ini merupakan sistem pendekatan pengembangan pembelajaran yang dilakukan meliputi 4 tahap yaitu pendefinisian, perancangan, pengembangan dan pendiseminasian.

Data yang telah dikumpulkan dengan menggunakan instrumen-instrumen seperti yang telah disebutkan diatas, selanjutnya dianalisis secara kuantitatif dan diarahkan unuk menjelaskan kevalidan, keefektifan dan kepraktisan modul pembelajaran matematika setting pembelajaran kooperatif tipe TPS yang tengah dikembangakan. Data yang diperoleh dari hasil validasi oleh para ahli dianalisis untuk menjelaskan kevalidan dan kelayakan penggunaan modul pembelajaran matematika berbasis kooperatif tipe TPS. Adapun data hasil uji coba di kelas digunakan untuk menjelaskan keefektifan dan kepraktisan modul pembelajaran matematika setting pembelajaran kooperatif TPS.

(1) Analisis Data Kesahihan/Validitas

Menurut pakar lawshe dan martuza (dalam Asdar, 2013:75) membahas metode statistika untuk menentukan validitas isi dan reliabilitas menyeluruh dari suatu tes melalui penilaian pakar. Relevansi kedua pakar secara menyeluruh merupakan validitas isi Gregory, yaitu berupa koefisien validitas isi. Koefisien validitas isi dapat dihitung dengan menggunakan rumus berikut:

$$
\text { Validitas Isi }=\frac{\mathbf{D}}{\mathbf{A}+\mathrm{E}+\mathbf{C}+\mathbf{D}}
$$

Keterangan:

$$
\text { A } \quad=\begin{aligned}
& \text { Sel yang menunjukkan kedua penilai/pakar menyatakan } \\
& \text { tidak relevan }
\end{aligned}
$$


$\mathrm{B}$ dan $\mathrm{C}=$ Sel yang menunjukkan perbedaan pandangan antar penilai/pakar.

$\mathrm{D} \quad=$ Sel yang menunjukkan persetujuan yang valid antara kedua penilai

Berikut ini adalah model kesepakatan antar penilai untuk validitas isi:

Validator I

\begin{tabular}{|c|c|c|c|}
\hline & & $\begin{array}{l}\text { Tidak relevan } \\
\text { Skor }(1-2)\end{array}$ & $\begin{array}{l}\text { Relevan } \\
\text { Skor (3-4) }\end{array}$ \\
\hline Gambar 3.1 & $\begin{array}{l}\text { Tidak relevan } \\
\text { skor }(1-2)\end{array}$ & $\mathbf{A}$ & B \\
\hline $\begin{array}{l}\text { antar dua pakar (dalam } \\
\text { Asdar, 2013:75) }\end{array}$ & $\begin{array}{l}\text { Relevan } \\
\text { Skor (3-4) }\end{array}$ & $\mathbf{C}$ & $\mathbf{D}$ \\
\hline
\end{tabular}

\section{(2) Analisis Data \\ Keefektifan}

Analisis terhadap keefektifan modul matematika setting pembelajaran kooperatif tipe TPS didukung oleh hasil analisis data dari 4 komponen keefektifan, yaitu (1) hasil belajar siswa atau ketuntasan klasikal, (2) respon siswa, (3) aktivitas siswa, dan (4) kemampuan guru dalam mengolah pembelajaran.

(3) Analisis Data Kepraktisan

Data kepraktisan perangkat modul matematika setting pembelajaran kooperatif tipe TPS diperoleh melalui dua cara yaitu (1) data dari kelayakan peneraan peangkat modul matematika setting pembelajaran kooperatif tipe TPS, dan (2) data dari pengamatan keterlaksanaan perangkat modul matematika setting pembelajaran kooperatif tipe TPS secara umum.

\section{HASIL PENELITIAN DAN PEMBAHASAN \\ Hasil Penelitian}

Berdasarkan proses yang dilakukan oleh peneliti dengan mengembangkan modul pembelajaran setting kooperatif tipe TPS adalah modifikasi dari teori pengembangan 4-D Thiagarajan yang meliputi tahapan (1) Studi pendahuluan (define) pada tahap ini peneliti Kegiatan yang dilakukan dalam tahap ini adalah analisis awal akhir, analisis siswa, analisis materi, analisis tugas, dan spesifikasi tujuan pembelajaran; (2) Tahap perancangan (design) dengan melakukan perancangan prototype perangkat pembelajaran. Hasil pada tahap perancangan (design) berupa perangkat modul matematika setting pembelajaran kooperatif tipe TPS dengan perangkat pendukung terdiri dari silabus, rencana pelaksanaan pembelajaran (RPP), dan tes hasil belajar.; (3) Tahap pengembangan (develop) 
dengan melakukan proses validasi kepada ahli sebanyak tiga kali proses validasi terhadap perangkat modul pembelajaran matematika setting kooperatif tipe TPS yang dikembangkan meliputi dua tahap validasi, yaitu tahap validasi terhadap hasil rancangan awal perangkat modul pembelajaran sebagaimana telah dikemukakan sebelumnya, serta validasi kedua dilakukan terhadap hasil revisi yang telah dilakukan berdasarkan saran-saran yang diberikan oleh tim validator dan pelaksanaan uji coba sebanyak satu kali terhadap subjek penelitian pada ahap ini peneliti melakukan obsevasi terhadap aktivitas siswa, hasil belajar siswa, kemampuan guru mengelola, keterlaksanaan pembelajaran, dan angket respons siswa; dan (4) Tahap penyebaran (disseminate) dengan melakukan sosialisasi produk kepada guru-guru bidang studi matematika untuk memperoleh masukan atau saran-saran sebagai masukan untuk melakukan revisi.

Berdasarkan hasil penelitian menunjukkan bahwa perangkat modul pembelajaran matematika yang dikembangkan dinyatakan valid, praktis, dan efektif berdasarkan penilaian validator dan hasil uji coba terbatas yang dilaksanakan. Kevalidan perangkat modul pembelajaran matematika diukur berdasarkan penilaian hasil validasi para ahli (validator) yang memenuhi kriteria kevalidan, yaitu (1) RPP dengan koefisien validitasnya adalah 100\% (2) modul pembelajaran matematika dengan koefisien validasnya adalah $85 \%$ dan (3) tes hasil belajar (THB) dengan koefisien validitasnya adalah 83,3\%. Ini menunjukkan bahwa perangkat modul pembelajaran matematika yang dihasil berada pada kategori valid. Kepraktisan perangkat diukur berdasarkan pengamatan keterlaksanaan perangkat modul pembelajaran matematika yang ditunjukkan terpenuhi kategori terlaksana seluruhnya. Keefektifan perangkat modul pembelajaran ditunjukkan dengan terpenuhinya 4 indikator keefektifan yang ditetapkan, antara lain (1) persentase rata-rata kelulusan klasikal tes hasil belajar sebesari 90,1\% (2) terpenuhinya 8 kategori aktivitas siswa, (3) lebih dari $80 \%$ siswa memberikan respon positif terhadap proses pembelajaran, modul pembelajaran matematika dan (4) kemampuan guru mengelola pembelajaran berada pada kategori baik.

\section{Pembahasan}

Berdasarkan hasil uji kevalidan yang telah dibahas sebelumnya dapat disimpulkan bahwa draft awal perangkat modul matematika setting pembelajaran kooperatif tipe TPS yang telah dikembangkan Rencana pelaksanaan pembelajaran, Modul pembelajaran matematika, Tes hasil belajar) seluruhnya telah memenuhi kriteria kevalidan seperti apa yang telah dikemukakan pada BAB III. Meskipun sebelumnya telah dilakukan beberapa revisi kecil sesuai saran yang diberikan oleh dua validator.

Berdasarkan hasil penilaian ahli dan praktisi dalam bidang pendidikan matematika terhadap modul matematika setting pembelajaran kooperatif tipe TPS yang telah dikembangkan layak untuk digunakan dalam proses pembelajaran. 
Sedangkan secara empirik, berdasarkan hasil pengamatan terahadap modul pembelajaran oleh observer menyatakan bahwa modul pembelajaran terlaksana dengan baik pada saat uji coba. Berdasarkan penilaian pengamat dan validator maka dapat disimpulkan bahwa perangkat pembelajaran memenuhi kriterian kepraktisan.

Berdasarkan Pada bab III telah dikemukakan kriteria keefektifan perangkat pembelajaran yang meliputi : (1) ketuntasan hasil belajar (2) aktivitas siswa (3) respon siswa dan (4) kemampuan guru mengelola pembelajara. Kriteria yang harus dipenuhi sehingga suatu perangkat modul pembelajaran dikatakan efektif adalah minimal 3 dari 4 kriteria tersebut terpenuhi, tetapi indicator 1 harus terpenuhi.

Dari ketiga indikator diatas, pada uji coba terbatas ketiga aspek tersebut terpenuhi, walapun terlalu maksimal sepenuhnya dalam proses pelaksanaannya. Beberapa hal yang turut mempengaruhi ketidakmaksimalan pengembangan modul matematika setting pembelajaran kooperatif tipe TPS adalah : (1) waktu yang digunakan untuk mengamati proses pelaksanaan pembelajaran siswa realatif singkat yakni enam kali pertemuan, sehingga proses untuk mengembangkan kemampuan siswa juga terbatas padahal antusias siswa belajar siswa sangat tinggi, (2) proses pembelajaran yang dialami siswa merupakan model pembelajaran yang relatif baru sehingga dibutuhkan waktu untuk beradaptasi sebab selama ini siswa lebih sering mendapatkan penjelasan detail dari guru, mereka kurang diajarkan bagaimana cara memperoleh sesuatu dari keraja keras yang mereka bangun. (3) hasil penilaian yang diberikan pengamat dan penilaian yang diberikan oleh siswa beradasarkan angket memiliki hasil yang kurang sesuai. Hal ini dipengaruhi oleh sikap dasar seseorang yang akan selalu memberikan penilaian yang positif terhadap dirinya sendiri sehingga sebagian besar penilaian diri yang dilakukan oleh siswa berada dalam kategori baik dan sangat baik.

Temuan-temuan khusus yang diperoleh peneliti selama melakukan uji coba perangkat modul matematika setting pembelajaran kooperatif tipe think pair share (TPS) di SMP Negeri 1 Pattallassang di kelas VII-A akan diuraikan sebagai berikut.

Temuan pertama menyangkut tentang hasil belajar siswa pada materi garis dan sudut. Penerapan pembelajaran matematika setting pembelajaran kooperatif tipe TPS telah memberikan dampak yang baik terhadap pencapaian ketuntasan hasil belajar siswa. Dianggap temuan khusus karena aspek inilah yang merupakan salah satu ciri yang membedakan antara perangkat modul matematika setting pembelajaran kooperatif dengan perangkat matematika yang sudah ada sebelumnya.

Temuan kedua menyangkut hasil uji coba, masih ada sebanyak 2 siswa dari 22 orang siswa atau sekitar $10 \%$ yang tidak tuntas. Dari 22 siswa yang mengikuti tes, terdapat 2 orang siswa $(10 \%)$ yang berada pada kategori sedang 
dan tidak pada kategori rendah maupun sangat rendah karena kedua siswa tersebtut kurang berpartisipasi dalam kelas atau sering absen.

Temuan ketiga menyangkut aktivitas siswa, selama kegiatan pembelajaran matematika setting kooperatif tipe TPS, siswa terlbat secara aktif sehingga dominasi guru dalam pembelajaran dapat berkurang. Dalam proses ini diharapkan siswa mampu mengembangkan aspek kognitifnya sesuai dengan kategori-kategori pengamatan aktivitas siswa yang diberikan. Secara umum hasil analisis siswa dan data aktivitas siswa menunjukkan bahwa kategori ke-1, ke-2, ke-3, ke-4, ke-5, ke6 , ke-7, dan ke-8 pada setiap pertemuan berada pada rentang batas toleransi. Sedangkan kategori ke-7 dan ke-8 perlu mendapatkan perhatian yang cukup dari guru.

Temuan keempat menyangkut respon siswa, pada uji coba menunjukkan lebih dari $80 \%$ siswa memberikan respon positif terhadap aspek-aspek modul matematika. Hasil analisis data respon siswa terhadap proses pembelajaran matematika setting kooperatif tipe TPS pada materi garis dan sudut menunjukkan bahwa rata-rata sebesar $95,24 \%$ siswa memberikan respon positif. Respon siswa terhadap modul matematika setting kooperatif tipe TPS dibuat dengan tujuan untuk mengetahui atau memperleh data tentang tanggapan atau pendapat siswa terhadap proses pembelajaran yakni termotivasi atau tidak, mengalami kemajuan atau tidak, suasana belajarnya, dampak atau pengaruh, kegiatan siswa, pemahaman terhadap materi. Adpun aspek yang dilihat pada angket respons siswa adalah respon kelayakan modul, penyajian materi, kelayakan bahasa, proses pembelajaran, dan penyajian soal.

Untuk mencapai kriteria kualitas hasil pengembangan perangkat modul matematika setting pembelajaran kooperatif tipe TPS tentunya terdapat keterbatasan yang dalam hal ini kondisi-kondisi tertentu yang tidak dapat dihindari. Namun, meskipun demikian penelitian tetap harus berjalan sesuai dengan batasan waktu dan kondisi lainnya yang ada. Beberapa keterbatasan yang ditemui di dalam penelitian ini dapat dijelaskan sebagai berikut.

(1) Modul pembelajaran ini awalnya direncanakan berbasis model pembelajaran kooperatif tipe TPS namun karena dalam proses validasi dan ujicoba modul yang digunakan tidak sepenuhnya berbasis model pembelajaran koperatif sehingga dilakukan perubahan yakni menjadi setting kooperatif karena pada proses pelaksanaan menggunakan tahap model kooperatif tipe TPS tersebut.

(2) Penelitian dilaksanakan hanya memuat cakupan terbatas, yakni materi yang dipilih di dalam penelitin ini hanya fokus pada satu materi yakni garis dan sudut.

(3) Uji coba hanya dilaksanakan pada satu sekolah yang memiliki karakteristik tidak selalu sama dengan sekolah lain, sehingga keberlakuan modul pada materi garis dan sudut setting pembelajaran kooperatif tipe think pair share (TPS) ini belum tentu menghasilkan dampak yang sama. 
Keterbatasan waktu penelitian sehingga tahap penyebaran dilaksanakan hanya secara terbatas dan sederhana sehingga hanya dilaksanakan pada sekolah penelitian dalam hal ini SMP Negeri 1 Pattallassang Kabupaten Gowa.

\section{SIMPULAN DAN SARAN \\ Simpulan}

Berdasarkan hasil penelitian dan pembahasan, maka kesimpulan dalam peneleitian ini adalah sebagai berikut: 1) Pada proses yang dilakukan oleh peneliti dengan mengembangkan modul pembelajaran setting kooperatif tipe TPS adalah modifikasi dari teori pengembangan 4-D Thiagarajan yang meliputi tahapan (1) Studi pendahuluan (define) pada tahap ini peneliti melakukan analisis pendahuluan terkait produk yang akan dihasilkan yang meliputi kegiatankegiatan: analisis awal akhir yang bertujuan untuk mengidentifikasi masalahmasalah yang dihadapi oleh guru SMP Negeri 1 Pattallassang khususnya guru matematika yang mengajar dikelas VII, analisis terhadap keadaan siswa yang ada di SMP Negeri 1 Pattallassang. Pada kegiatan ini, peneliti menelaah tenatang latar belakang pengetahuan siswa, bahasa yang digunakan dan tingkat perkembangan kognitif siswa, pada analisis lingkungan peneliti merancang perangkat modul pembelajaran matematika setting kooperatif dengan menampilkan beberapa contoh dalam kehidupan sehari-hari atau telah dikenal siswa, pada analisis konsep kegiatan yang dilakukan pada tahap ini adalah mengidentifikasi, merinci, dan menyusun secara sistematis materi-materi utama yang dipelajari siswa, selanjutnya materi tersebut disusun secara hirarkis, pada analisis tugas hasil analisis tugas untuk materi garis dan sudut pada penelitian ini yaitu menemukan konsep garis dan sudut, menentukan kedudukan garis, menjelaskan hubungan antar sudut, dan pada analisis spesifikasi tujuan langkah ini untuk mengkonversi hasil analisis materi yang dinyatakan dalam bentuk tingkah laku siswa menjadi tujuan pembelajaran; (2) Tahap perancangan (design) dengan melakukan penyusunan tes yaitu tes yang digunakan dalam penelitian ini berbentuk pilihan ganda dengan jumlah soal 25 butir soal, pada pemilihan media ditentukan bahwa media pembelajaran yang diperlukan dalam pelaksanaan pembelajaran matematika model kooperatif tipe think pair share (TPS) meliputi: RPP, Modul, dan THB. Sedangkan alat bantu pembelajaran: papan tulis, spidol, penghapus, Mistar/penggaris dan pulpen/pensil, pada pemilihan format di dalam RPP khususnya di setiap aspek kegiatan siswa dimasukkn aspek scientifiknya, sedangkan format Modul, dan THB dibuat berwarna, teratur, rapih, terstruktur sehingga siswa akan tertarik, termotivasi dan mudah untuk belajar, dan perancangan awal modul pembelajaran dalam hal ini rancangan awal yang dibuat adalah modul pembelajaran, lembar validasi modul pembelajaran, angket respon guru dan respon siswa terhadap modul pembelajaran berbasis kooperatif tipe TPS dan tes hasil belajar (THB). Selanjutnya rancangan awal ini disebut sebagai Draft 
I; (3) Tahap pengembangan (develop) dengan melakukan proses validasi kepada ahli sebanyak tiga kali proses validasi terhadap perangkat modul pembelajaran matematika setting kooperatif tipe TPS yang dikembangkan meliputi dua tahap validasi, yaitu tahap validasi terhadap hasil rancangan awal perangkat modul pembelajaran sebagaimana telah dikemukakan sebelumnya, serta validasi kedua dilakukan terhadap hasil revisi yang telah dilakukan berdasarkan saran-saran yang diberikan oleh tim validator dan pelaksanaan uji coba sebanyak satu kali terhadap subjek penelitian pada ahap ini peneliti melakukan obsevasi terhadap aktivitas siswa, hasil belajar siswa, kemampuan guru mengelola, keterlaksanaan pembelajaran, dan angket respons siswa; dan (4) Tahap penyebaran (disseminate) dengan melakukan sosialisasi produk kepada guru-guru bidang studi matematika untuk memperoleh masukan atau saran-saran sebagai masukan untuk melakukan revisi. 2) Secara keseluruhan mulai dari tahapan proses pengembangan sampai ke tahap hasil pengembangan modul pembelajaran matematika setting pembelajaran kooperatif tipe think pair share (TPS) pada penelitian ini telah memenuhi kriteria produk berkualitas yang dikemukakan oleh Nieveen yakni valid, praktis, dan efektif. Dengan perangkat pendukung diantaranya adalah RPP, dan Tes Hasil Belajar (THB) telah memenuhi kriteria valid.

\section{Saran}

Berdasarkan kesimpulan di atas, maka penulis menyarankan beberapa hal yang perlu diperhatikan: 1) Bagi calon peneliti yang ingin melanjutkan penelitian ini agar membuat kegiatan pembelajaran sesuai dengan jumlah pertemuan yang dilakukan disekolah. 2) Agar pengembangan modul matematika setting pembelajaran kooperatif tipe TPS ini lebih sempurna kiranya calon peneliti memperhatikan betul keterkaitan antara masalah yang ada pada uaraian materi dengan latihan kerja siswa. 3) Modul pembelajaran matematika setting kooperatif tipe think pair share (TPS) yang dihasilkan pada penelitian ini hanya diujicobakan pada satu kelas. Hanya uji coba ini yang dijadikan sebagai dasar pertimbangan dalam melakukan revisi modul yang telah dikembangkan. Oleh karena itu untuk memperoleh hasil yang lebih baik disarankan untuk melakukan ujicoba pada skala yang lebih luas.

\section{DAFTAR PUSTAKA}

Asdar, Ahsanul Khaer. 2013. "Pengembangan Perangkat Asesmen Alternatif Pada Pembelajaran Dimensi Tiga Setting Kooperatif Pada Siswa Kelas XI SMK. Tesis tidak diterbitkan. Makassar: UNM.

Ardin. 2013. Keefektifan Pembelajaran Matematika Realistik Setting Kooperatif Tipe Nht Pada Materi Pokok Ruang Dimensi Tiga. Tesis tidak diterbitkan. Makassar: UNM. 
Asri, Syamsul. 2012. "Pengembangan Perangkat Pembelajaran Koopertaif Dengan Pendekatan Realistik Pada Siswa Kelas VIII SMPN 5 Bontomatene Kabupaten Kepulauan Selayar. Tesis tidak diterbitkan. Makassar: UNM.

BSNP. (2006). Standar Isi Mata Pelajaran Matematika SMP. Jakarta : Depdiknas.

Cholis, Nur. 2006. Pembelajaran Kooperatif. Departemen Pendidikan Nasional Direktorat Pendidikan Dasar dan Menengah Lembaga Penjamin Mutu Jawa Timur. PDF, (Diakses pada tanggal 23 November 2013 pukul 17.00 WITA)

Depdiknas. (2007). UU Sisdiknas No 20. Jakarta: Pusat Kurikulum, Badan Penelitian dan Pengembangan Depdiknas.

Depdiknas. (2008). Panduan Pengembangan Bahan Ajar. Jakarta: Direktorat Pembinaan Sekolah Menengah Atas.

Depdiknas. 2008. Kamus Besar Bahasa Indonesia (KBBI). Pusat bahasa Depdiknas: Jakarta

Huda, Miftahul. 2012. Cooperative Leraning. Pustaka Pelajar: Yogyakarta.

Komalasari, K. 2011. Pembelajaran Kontekstual Konsep dan Aplikasi. Bandung: PT Revika Aditama

Lie, Anita. 2004. Cooperative Learning. Jakarta: Grasindo.

Nurdin, Syafruddin. 2005. Model Pembelajaran Yang Memperhatikan Keragaman Individu Siswa Dalam Kurikulum Berbasis Kompetensi. Ciputat Press: Jakarta.

Riadi, Muchlisin. 2013. Pengertian, Kelebihan dan Kekurangan Modul Pembelajaran. (http:///G:/pengertian, kelebihan dan kekurangan modul pembelajaran.html, Diakses pada tanggal 23 November 2013 pukul 17.00 WITA).

Vembriarto, St. (1975). Pengantar Pengajaran Modul. Yogyakarta: Yayasan Pendidikan Paramita.

Wijaya, Cece. 1991. Upaya Pembaharuan Dalam Pendidikan dan Pengajaran. Remaja Rosda Karya: Bandung.

Winkel. 2009. Psikologi Pengajaran. Yogyakarta: Media Abadi 